\title{
Improving Productivity of Traditional Andean Small Famers by Bio-Rational Soil Management I. The Potato Case
}

\author{
J. Franco; G. Main; O. Navia, N. Ortuño and J. Herbas ${ }^{1}$
}

\section{Summary}

The use of chemical pesticides in agriculture demands high investments; its in discriminated and inadequate application to obtain immediate crop response has caused considerable damage to the environment and human health, either due to a direct effect or indirect contamination of farmer fields and water sources by highly toxic products. On the other hand, as a result of soil fertility losses, farmers move to new areas for farming, causing a complex migration phenomena and devastation of natural forests. In an effort to find new alternatives for the management of crop pests compatible with the environment and agroecologically friendly, some technologies recently developed have been offered to small Andean potato farmers. Among these, the recycling of organic residues and the management of natural soil microorganisms which are important alternatives to reduce the importation and use of toxic agro-chemicals as well as to preserve and recuperate soil fertility and thus reach a sustainable potato production by Andean farmers. This will not only guarantee food security, but will also have favorable impact on the yield and quality of potato and other crops.

Additional index words:

Compost, arbuscular mycorrhizal fungi (AMF), plant growth promoting rizhobacterias (PGPR), Glomus fasciculatum, Bacillus subtilis, $B$. amyloliquefaciens

Accepted for publication: December 28, 2011

\footnotetext{
${ }^{1}$ Researches ; Fundación para la Promoción e Investigación de Productos Andinos (PROINPA), Cochabamba, Bolivia, E-Mail: j.franco@proinpa.org
} 
Mejorando la productividad de pequeños agric ultores

Andinos, mediante el uso racional de productos biológic os en el manejo del suelo. I: E caso del cultivo de papa

\section{Resumen}

El empleo de agroquímicos en la agricultura demanda la inversión de grandes capitales y su uso indiscriminado e inadecuado al largo plazo, ha venido causando daño considerable al medio ambiente y la salud de la población. Además su uso indiscriminado para el control de plagas y enfermedades en cultivos, es la causa de casos de envenenamiento y muerte de agricultores y sus familiares, así como también de especies animales que comparten su territorio, por la acción directa o contaminación de sus campos y ríos. Por otro lado, se tiene el abandono de tierras agrícolas como consecuencia de la pérdida de la fertilidad de sus suelos, que lleva a los campesinos a incorporar nuevas áreas, contribuyendo a la deforestación, con los problemas consiguientes de desplazamiento y migración de poblaciones. En la búsqueda, por un lado, de nuevas alternativas de manejo de plagas y enfermedades de los cultivos que sean compatibles con el medio ambiente y, por el otro, con el manejo del agro-ecosistema con la finalidad de recuperar o mantener la fertilidad de sus suelos, se han desarrollado tecnologías que se proponen para su adopción por parte de los pequeños productores andinos. Entre estas, el reciclamiento de residuos orgánicos y el manejo de microorganismos naturales del suelo constituyen alternativas importantes tanto para disminuir el uso de agroquímicos y la dependencia de la importación de insumos como para la recuperación de la fertilidad de los suelos agrícolas y para tender a una producción sostenible en los Andes que proporcione seguridad alimentaria a todos sus pobladores. 
plantas (PGPR), Glomus fasciculatum, Bacillus subtilis, B. amyloliquefaciens.

\section{Introduction}

Agricultural soils in the central Andes are generally characterized by low fertility and low organic matter content $(0.5$ to $2 \%$ ). Under those conditions, yield of most Andean crops are especially constrained by low soil levels of $\mathrm{N}$ and $\mathrm{P}$. Resource poor farmers in Bolivia and Peru use low fertilizer levels, 2.8 and 22.6 of NPK Units per ha, respectively, as compared to other countries of the region like Venezuela and Colombia which use 122 and 139 NPK Units per ha respectively (FAOSTAT, 2008).

The Central Andean Highlands are the center of origin of the potato (Solanum spp.) and a major center of diversity, with over 4000 different native potato cultivars grown by farmers (CIP, 2007). For centuries, indigenous farmers have selected landraces adapted to harsh and variable agro-ecological conditions, and managed the land with minimal inputs to achieve sustainable yields. Hence, potato is grown and adapted to a huge variety of agro-ecosystems, soils and land use systems. Nowadays farmers employ a wide range of cropping systems, comprising high input systems with fertilizer applications of up to $500 \mathrm{~kg} \mathrm{NPK} \mathrm{ha}{ }^{-1}$ and frequent pesticide use, to low-input subsistence systems with limited manure application and almost no pesticides. Yield levels are medium to low, ranging between 15 and $20 \mathrm{t} \mathrm{ha}^{-1}$ for high input and 5 to $8 \mathrm{t} \mathrm{ha}^{-1}$ for low input systems (Davies Jr. et al., 2005; MINAG, 2007). As a result, pests and diseases increasingly affect potato crop reducing tuber yield, but above all, tuber quality, rendering them unfit for commercial use. In these conditions soil fertility management has also a prominent role for crop productivity. An appropriate soil fertility management guarantees a certain level of yield stability, even in difficult agro-ecological conditions, and increases the overall resilience of the cropping system to adverse biotic and/or a biotic stresses (Fliessbach et al., 2007, Karlen et al., 1997, Mallory and Porter, 2007). The increased 
food production required to feed the growing population would have to come from "land saving" technologies, oriented to intensify the production of the system, converting marginal lands into productive areas, and the restoration of degraded areas (Lal, 2000). These types of technologies include, for example, increasing crop nutrient use efficiency, control of biotic constraints and soil-water conservation practices, particularly under rain fed conditions, as it occurs in the Andes.

Soil microbes are key-components of all agricultural systems, exerting multiple functions, from detrimental (e.g. pathogenic) to beneficial, in particular in low input systems, (e.g. plant growth promoters and pathogen antagonists), hence impacting yield and quality of food. Nowadays, increasing attention is devoted to rhizosphere and endophytic microbes which play a central role in promoting plant growth and health. It has been stated that "the ultimate agricultural goal in studies of the biology of the soilroot interface, must be the manipulation of microorganisms in this zone to increase plant health and growth" (Rovira, 1979). To this end, research should aim at improving our knowledge of the interactions between plants and microbes, and of sustained management of these microbes to benefit the plant-foodconsumer chain. This knowledge could help to reduce excessive use of agrochemicals, thus alleviating hazardous effects of agricultural production on the environment. Combining suited potato 'genotypes', proper land management and inoculation with appropriate beneficial microbes, e.g. arbuscular mycorrhizal fungi (AMF), plant growth promoting rhizobacteria (PGPR) and pathogen antagonists therefore becomes a major challenge for the sustainable intensification of potato-based farming systems in the Andean area.

Recycling of organic waste - using the power of microorganisms - to a safe and useful end product (compost) is a realistic option aimed at improving crop production. Besides, the management of natural microbial soil biota, which positively impact plant development, nutrition and health - arbuscular mycorrhizal fungi (AMF) and plant growth promoting bacteria (PGPR) - has been recognized as a major agricultural practice to reduce chemical inputs like pesticides and fertilizer, and to improve the ecological 
potential and sustainability of soils in Andean cropping systems. Major benefits for plants include improved nutrient uptake and increased tolerance/resistance to a biotic and biotic stresses. These environmental-friendly, natural bio-fertilizers and bioprotectors represent a major opportunity, for cost savings which are often too high for small-scale, resource-poor agricultural systems. Many previous studies and reviews have reported plant growth promotion, increased yield, solubilization of $\mathrm{P}$ or $\mathrm{K}$, uptake of $\mathrm{N}$ and other nutrients through inoculation with PGPR (de Freitas et al. 1997; Rodriguez and Fraga 1999; Joo et al. 2004; Sheng and He 2006; Glick et al. 2007). Arbuscular mycorrhiza fungi (AMF) are other microbial inoculants that can influence plant growth and water and nutrient uptake. It has been reported that extra radical hyphae of AMF act as a bridge between the soil and plant roots, and their effectiveness is affected by soil $\mathrm{P}$ concentration (Duffy et al.1999; Liu et al. 2000; Bianciotto and Bonfante 2002; Stewart et al. 2005).

As indicated, potato production in the Andean region is constrained as a result of various a biotic and biotic soil problems and access to pesticides and fertilizers is frequently too expensive. A project, financed by EC, for recycling organic waste into compost, and management of soil natural microbes, AMF and PGPR - was carried out to reduce chemicaldependence of small-scale, resource-poor farmers, and to improve the ecological potential and sustainability of soils in rural and peri-urban systems (Franco et al. 2004). The project stimulates local collective capacities to develop micro-scale composting systems and management of microbial inoculants. The present study was conducted as part of this project, and aims at investigating local compost preparation and PGPR, AMF, and their combination, as microbial inoculants, for effects on potato growth in farmer fields.

\section{Materials and Methods}

Participatory farmer field trials were conducted. in the Andean region of Bolivia (Lope Mendoza, 3440 masl, Carrasco Province; Tiraque highlands, 3453 masl, Tiraque province; La Villa, 2650 
masl, Cochabamba province and Colomi, 3200 masl, Chapare Province).

The field trials were established in different agro-ecological zones of the Department of Cochabamba, in order to evaluate the following strategies of integrated soil management (ISM):

I. Compost was prepared by farmers using post- harvest organic residues including organic fertilizers. This local "farmer compost", 7 t/ha, was compared to chicken manure plus chemical fertilizers ( $3 \mathrm{t} / \mathrm{ha}+18-46-00 \mathrm{k} / \mathrm{ha}$ ), applied at planting time at the bottom of furrows. These trials were established in 4 fields at different locations to study the effect of incorporating 7 t/ha of compost prepared by farmers using post - harvest organic residues. Each farmer field was considered as a replicate for statistical analysis.

Following harvest, the potato crop was followed by faba beans crop (Vicia faba) to establish the residual effect of applied compost treatments on yield of the faba bean crop. As above each field was considered a replicated treatment.

II. Application of commercial products of Bacillus subtilis and the arbuscular mycorrhizal fungi (AMF) Glomus fasciculatum using the potato local cultivar "Waycha" (Solanum tuberosum ssp andigena) and/or "Desirée" ( $S$. tuberosum ssp. tuberosa) a very common European variety: The bacteria= based products were applied as single or mixed treatment with $G$. fasciculatum and always associated to the incorporation of compost (7 t/ha) at planting time. Powder commercial product of the bacteria B. subtilis (250 g / ha), and other local made granular bio-fertilizers containing micorrhyza $G$. fasciculatum (15 kg / ha) in 200 litres of water were sprayed on the compostor other organic fertilizers, placed at the bottom of furrows at planting time. Recommended dosages of $B$. subtilis and $G$. 
fasciculatum were prepared and mixed as needed for field trials, and

III. Application of a native Bolivian isolate of $B$. amyloliquefaciens and $B$. subtilis on traditional potato cultivar Waycha were also evaluated, as single treatments, and the incorporation ( $7 \mathrm{t} / \mathrm{ha}$ ) at planting time of the potato crop in three farmer fields.

\section{Conditions of experimental assays:}

I. Local farmer compost

- Potato cultivars: Waycha (Solanum tuberosum ssp andigena)

- Compost and rates:

- Local farmer compost was prepared with post-harvested organic residues ( $7 \mathrm{t} / \mathrm{ha}$ )

- Improved fertilizer: Chicken manure and synthetic fertilizers ( $3 \mathrm{t} / \mathrm{ha}+18-46-00 \mathrm{k} / \mathrm{ha})$

- Application time and placement: at planting at the bottom of furrows.

- Residual effect of compost on the faba bean crop

II. Micro inoculants: Experiments were conducted in three farmer fields using traditional agronomic practices. The only introduced modification was the application of inoculants.

- Potato cultivars:

- Waycha (Solanum tuberosum ssp andigena) and Desirée (S. tuberosum ssp tuberosa).

- Inoculant rates:

- FZB 24WG (B. subtilis): $250 \mathrm{~g} / 100 \mathrm{~L}$ water/ha: $2.5 \mathrm{~g} / \mathrm{llt}$ $1100 \mathrm{~m} 2$ (at bottom of row on seed tuber cover with compost). 
- $\quad$ AMF commercial: $15 \mathrm{~kg} / 100 \mathrm{~L}$ water/ha; $150 \mathrm{~g} / 100 \mathrm{~m} 2$ (water can be doubled to $200 \mathrm{~L}$ to avoid clogging)

- Experimental inoculant rates:

- FZB 24WG (B. subtilis): $0.625 \mathrm{~g} / 25 \mathrm{~m} \times 4$ reps $=2.5 \mathrm{~g} / \mathrm{cv}$; $5 \mathrm{~g} /$ treatment field trial $(5 \mathrm{~g}$ alone and $5 \mathrm{~g}$ combined with AMF)

- $\quad$ AMF commercial: $37.5 \mathrm{~g} / 25 \mathrm{~m}$ x 4 reps $=150 \mathrm{~g} / 100 \mathrm{~m} 2$

- Compost rate:

- Compost (post harvest residues + cow manure): 8000 kg /ha; 800 kg / field

- Field design:

- $\quad$ Replicates per treatment $=4$

- $\quad$ Experimental units $=4$ replicates $\times 8$ treatments $=32$

- $\quad$ Plants per experimental unit $=85$ (17 lines $\times 5$ rows)

- Row's length $=5 \mathrm{~m}$; Row's width $=0.70 \mathrm{~m}$; Distance between plants $=0,30 \mathrm{~m}$

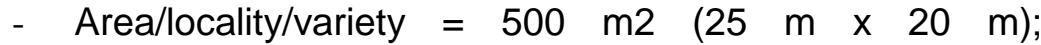
Area/locality/ 2 variety $=1000 \mathrm{~m} 2(50 \mathrm{~m} \times 20 \mathrm{~m})$

- $\quad$ Plants analyzed per experimental unit $=45$ (border lines were not included in the analyses).

- Seed tubers:

- 85 tubers/exp. unit; $85 \times 4$ treat. $\times 4$ rep. $=1360$ potato seed tubers/field

- $\quad$ Seed weight $=40 \mathrm{gr}$ each; Total seed / field trial $=55 \mathrm{~kg}$;

- Total seed x 3 localities $=165 \mathrm{~kg} /$ variety

III. B. amyloliquefaciens native inoculants

- Potato cultivars:

- Waycha (Solanum tuberosum ssp andigena)

- Experimental inoculation rates:

- $\quad$ FZB 24WG (B. subtilis): $0.625 \mathrm{~g} / 25 \mathrm{~m} \times 4$ reps $=2.5$ $\mathrm{g} / \mathrm{cv} ; 5 \mathrm{~g} /$ treatment field trial

- B. amyloliquefaciens: $0.625 \mathrm{~g} / 25 \mathrm{~m} \times 4$ reps $=2.5 \mathrm{~g} / \mathrm{cv}$; $5 \mathrm{~g} /$ treatment field trial

- Compost rate:

- Compost (post harvest residues + cow manure): $8000 \mathrm{~kg}$ /ha; $800 \mathrm{~kg} /$ field 
- Field design and number of seed tubers were the same as with $B$. subtilis.

Parameters evaluated: Similar evaluation parameters were used in all field trials.

- Compost field experiments:

- Potato crop development and yield in four fields

- Faba bean yield in three fields

- Bio-inoculants experiments:

- $\%$ emergence $=$ number of tubers that give rise to a plant

- Tuber fresh and dry weight

- Number of tubers

- Tuber size

- Other aspects

- Other contaminants : Rhizoctonia - Phytophthora

\section{Results and Disc ussion}

\section{Effect of local farmer compost}

In first place, results of participatory potato farmer field trials showed that micro-scale composting production, based on organic waste from rural post-harvest residues, in combination with animal manures, represent an alternative to chemical fertilizers.

Potato yields obtained in each farmer field, were higher than traditional farmer plots and calculated mean was statistically superior (Table 1); farmers were able to prepare their own compost and appreciated its advantages for crops and soil conservation. The residual effect of compost incorporation on yield of the next crop after potato was evident to farmers (Table 2). 
Table 1. Potato yield from farmer field trials with local farmer compost and chemical fertilizers in a pilot area of Lope Mendoza (Carrasco province, Cochabamba, Bolivia)

\begin{tabular}{|c|c|c|c|}
\hline Community & Replicate / Farmer & Treatments & Yield (t/ha) \\
\hline \multirow{2}{*}{ Lope Mendoza Alto } & \multirow{2}{*}{ I. Froylan Aguilar } & Farmer compost & 28.6 \\
\hline & & Chicken manure + 18-46-00* & 23.8 \\
\hline \multirow{2}{*}{ Ch'ullchonq'ani } & \multirow{2}{*}{ II. Demetrio Gutiérrez } & Farmer compost & 29.0 \\
\hline & & Chicken manure + 18-46-00 & 24.5 \\
\hline \multirow{2}{*}{ El Puente } & \multirow{2}{*}{ III. Isabel Pérez vda. de Almanza } & Farmer compost & 25.5 \\
\hline & & Chicken manure + 18-46-00 & 22.5 \\
\hline \multirow{3}{*}{ Lope Mendoza Alto } & \multirow{2}{*}{ IV. Froylan Aguilar } & Farmer compost & 30.9 \\
\hline & & Chicken manure + 18-46-00 & 25.7 \\
\hline & Means & $\begin{array}{l}\text { Farmer compost } \\
\text { Chicken manure }+18-46-00\end{array}$ & $\begin{array}{l}28.5(a)^{* *} \\
24.1(b)\end{array}$ \\
\hline
\end{tabular}

* 40-60-00(N-P-K kg/ha); **: Means showing significant differences at $p=.05$ 
Table 2. Residual effect of local farmer compost applied to a previous potato crop on faba bean (Vicia faba) fresh weight in a pilot area of Lope Mendoza (Carrasco province, Cochabamba, Bolivia)

\begin{tabular}{|c|c|c|c|}
\hline Farmer & Current crop & $\begin{array}{c}\text { Treatments to a previous } \\
\text { potato crop }\end{array}$ & $\begin{array}{l}\text { Fresh pod yield } \\
\text { (t/ha) }\end{array}$ \\
\hline \multirow{2}{*}{ Patricio Montaño (Muyurina) } & \multirow{2}{*}{ V. faba } & Farmer Compost & 20.0 \\
\hline & & Chicken manure + 18-46-00* & 19.0 \\
\hline \multirow{2}{*}{ Froilan Aguilar (Lope Mendoza Alto) } & \multirow{2}{*}{ V. faba } & Farmer Compost & 21.5 \\
\hline & & Chicken manure + 18-46-00 & 19.5 \\
\hline \multirow{2}{*}{ Demetrio Gutierrez (Ch'ullchonq'ani ) } & \multirow{2}{*}{ V. faba } & Farmer Compost & 22.5 \\
\hline & & Chicken manure + 18-46-00 & 18.5 \\
\hline Means & V. faba & $\begin{array}{l}\text { Farmer compost } \\
\text { Chicken manure }+18-46-00\end{array}$ & $\begin{array}{l}21.4(a)^{\star *} \\
19.0(b)\end{array}$ \\
\hline
\end{tabular}

* 40-60-00(N-P-K kg/ha); **: Means showing significant differences at $p=.05$ 


\section{Effect of micro inoculants: Use of Commercial Bio- fertilizers}

Once farmers adopted micro-scale composting production, based on available organic rural post-harvest residues (potato, peas, barley straw, wheat,etc.) and farm animal manures (chicken,cow,sheep).Potato field trials were established to evaluate of standard formulated composts as single treatment, or in combination with commercial available AMF (Glomus fasciculatum) and PGPR (Bacillus subtilis), with the participation of local farmers. Plant growth and yield were evaluated with farmers' participation.

Initial results with potatoes showed that treatments combining $B$. subtilis with organic amendments resulted in superior and uniform plant emergence, higher plant vigor and development, improved plant health, and higher yield of tubers, as compared to treatments without $B$. subtilis. The combined use of compost and $B$. subtilis confirmed their role as plant growth promoter and plant pathogen suppressor (i.e. R. solani).

Other results showed that $B$. subtilis and AMF treatments had significantly higher yields than farmer control plots but significantly lower yields as compared to the combination of $B$. subtilis and AMF. The combination of B.subtilis and AMF suggests a strong synergistic effect between the two microbial inoculants. Results of field trials with the potato cultivars Waycha (Solanum tuberosum ssp andigena) and Desiree (S. tuberosum ssp. tuberosa) confirmed the positive effects on tuber yield of both, micro inoculants and the incorporation of compost (Table 3).

Harvested tubers of cvs. Desiree and Waycha were evaluated for the presence of $R$. solani. Although no statistical analysis was applied to results, incidence of $R$. solani was lower in treated tubers with micro inoculants, either as single or combined applications (Table 4). These results would confirm the suppressive effect of PGPR such as $B$. subtilis and the AMF $G$. fasciculatum, observed on the incidence of other soil-borne diseases in different crops. 
Table 3. Yield of potato cultivars Desirée and Waycha (t/ha) and its relation with check (\%), as influence by the application of two biological products under three different agro ecological conditions (Cochabamba, Bolivia)

\begin{tabular}{|c|c|c|c|c|c|c|}
\hline Treatments & Desirée & Waycha & Desirée & Waycha & Desirée & Waycha \\
\hline FZB 24WG (B. subtilis) & $\begin{array}{c}31.93\left(b^{\star}\right) \\
(52.8 \%)\end{array}$ & $\begin{array}{c}32.66(\mathrm{~b}) \\
(46.4 \%)\end{array}$ & $\begin{array}{l}29.62(a) \\
(50.4 \%)\end{array}$ & $\begin{array}{l}34.57(a) \\
(31.1 \%)\end{array}$ & $\begin{array}{l}35.82(a) \\
(25.4 \%)\end{array}$ & $\begin{array}{l}28.87(a) \\
(32.6 \%)\end{array}$ \\
\hline DESAmic (G. fasciculatum) & $\begin{array}{l}29.42(\mathrm{c}) \\
(40.8 \%)\end{array}$ & $\begin{array}{l}30.03(\mathrm{c}) \\
(34.6 \%)\end{array}$ & $\begin{array}{l}25.76(b) \\
(30.8 \%)\end{array}$ & $\begin{array}{l}\text { 32.42(b) } \\
(22.9 \%)\end{array}$ & $\begin{array}{l}34.78(a) \\
(21.8 \%)\end{array}$ & $\begin{array}{c}26.64(b) \\
(22.4 \%)\end{array}$ \\
\hline FZB 24WG + DESAmic & $\begin{array}{l}33.66(a) \\
(61.1 \%)\end{array}$ & $\begin{array}{l}35.71(a) \\
(60.1 \%)\end{array}$ & $\begin{array}{l}28.60(a) \\
(45.3 \%)\end{array}$ & $\begin{array}{l}34.08(a) \\
(29.2 \%)\end{array}$ & $\begin{array}{l}37.09(\mathrm{a}) \\
(29.9 \%)\end{array}$ & $\begin{array}{l}29.25(a) \\
(34.4 \%)\end{array}$ \\
\hline Check & $20.89(d)$ & $22.31(d)$ & $19.69(\mathrm{c})$ & $26.37(\mathrm{c})$ & $28.56(b)$ & $21.77(\mathrm{c})$ \\
\hline Department & \multicolumn{2}{|c|}{ Cochabamba } & \multicolumn{2}{|c|}{ Cochabamba } & \multicolumn{2}{|c|}{ Cochabamba } \\
\hline Locality & \multicolumn{2}{|c|}{ Chullchungani } & \multicolumn{2}{|c|}{ Colomi } & \multicolumn{2}{|c|}{ Paracaya } \\
\hline Soil type & \multicolumn{2}{|c|}{ Sand-loamy } & \multicolumn{2}{|c|}{ Loamy } & \multicolumn{2}{|c|}{ Silt-loamy } \\
\hline O.M. and $\mathrm{pH}$ & \multicolumn{2}{|c|}{$7.0 \%-3.57$} & \multicolumn{2}{|c|}{$8.7 \%-3.87$} & \multicolumn{2}{|c|}{$2.6 \%-6.37$} \\
\hline Altitude (masl) & \multicolumn{2}{|c|}{3000} & \multicolumn{2}{|c|}{3200} & \multicolumn{2}{|c|}{2700} \\
\hline Precipitation (mm) & \multicolumn{2}{|c|}{1000} & \multicolumn{2}{|c|}{1200} & \multicolumn{2}{|c|}{550} \\
\hline
\end{tabular}

${ }^{*}$ Numbers followed for the same letter are not statistically different at $\mathrm{p}=.95$ 
Table 4. Incidence of Rhizoctonia solani on tubers of potato cultivars Desirée and Waycha, treated with two biological products, under three different agro ecological conditions of (Cochabamba, Bolivia)

\begin{tabular}{|l|c|c|c|c|c|c|}
\hline \multicolumn{1}{|c|}{ Treatments } & Desirée & Waycha & Desirée & Waycha & Desirée & Waycha \\
\hline FZB 24WG (B. subtilis) & $2.3^{\star} / 0.0$ & $1.8 / 0.0$ & $1.5 / 0.0$ & $1.5 / 0.0$ & $2.0 / 0.0$ & $1.8 / 0.0$ \\
\hline DESAmic (G. fasciculatum) & $7.0 / 0.0^{\star \star}$ & $6.0 / 0.0$ & $5.5 / 0.0$ & $5.5 / 0.0$ & $6.5 / 0.0$ & $7.3 / 0.0$ \\
\hline FZB 24WG + DESAmic & $1.8 / 0.0$ & $1.5 / 0.0$ & $1.0 / 0.0$ & $1.3 / 0.0$ & $1.5 / 0.0$ & $1.8 / 0.0$ \\
\hline Check (100 \%) & $23.5 / 3.0$ & $22.5 / 2.0$ & $20.5 / 1.8$ & $20.3 / 2.0$ & $23.0 / 2.0$ & $25.5 / 1.5$ \\
\hline
\end{tabular}

*: \% skin damage incidence; **: \% sclerotia incidence 
Table 5. Yield of potato $\mathrm{cv}$. Waycha (t/ha) and its relation with control (\%), as influenced by the application of the biological products, B. subtilis (FZB 24WG), and a native isolate of $B$. amyloliquefaciens in three farmer fields under different agro ecological conditions in Cochabamba, Bolivia

\begin{tabular}{|l|c|c|c|}
\hline \multicolumn{1}{|c|}{ Treatments } & $\begin{array}{c}\text { Potato cv. } \\
\text { Waycha }\end{array}$ & $\begin{array}{c}\text { Potato cv. } \\
\text { Waycha }\end{array}$ & $\begin{array}{c}\text { Potato cv. } \\
\text { Waycha }\end{array}$ \\
\hline Native B. amyloliquefaciens & $\mathbf{3 0 . 0 ( 3 6 . 4 \% )}$ & $\mathbf{1 4 . 0 ( 9 1 . 0 \% )}$ & $24.9(38.3 \%)$ \\
\hline FZB 24WG (B. subtilis) & $29.0(31.8 \%)$ & $11.6(57.7 \%)$ & $\mathbf{2 5 . 5 ( 4 1 . 7 \% )}$ \\
\hline Control (100\%) & 22.0 & 7.3 & 18.0 \\
\hline
\end{tabular}




\section{Inoculation with native $B$. amyloliquefaciens}

Although no statistically analysis were performed to compare obtained potato yields in farmer fields, treatments of native micro inoculant resulted superior than $B$. subtilis concerning plant growth and yield (Table 5). Due to the positive results obtained with the application of the native isolate of $B$. amyloliquefaciens, as single treatment or mixed with $G$. fasciculatum, and vermicompost, on several horticultural and orchard crops, a bio fertilizer was formulated and used by farmers dedicated to organic production. Once an efficient and effective native isolate of AMF can be produced locally, it will be used as ingredient for replacing the commercial DESAmic product of $G$. fasciculatum. The local formulation of biofertilizers, and the recommended incorporation of compost, locally prepared by farmers, is playing a key role in improving or maintaining soil fertility in conventional and organic agriculture, as well as in improving the livelihood of resource-poor small Bolivian producers and urban consumers.

In order to promote the adoption of composting and microbial inoculant products, innovations by small rural and peri-urban farmers, numerous contacts were made with various stakeholders, including farmers associations, and individual farmers; project activities have been locally diffused through documents and publications. The training program and diffusion related to composting, bio-fertilizes use, soil management, and complementary activities like community organization and organic agriculture was carried out by means of field days (Figure 1) in collaboration with local actors, including municipalities and PROINPA, a Bolivian National foundation. 
a.

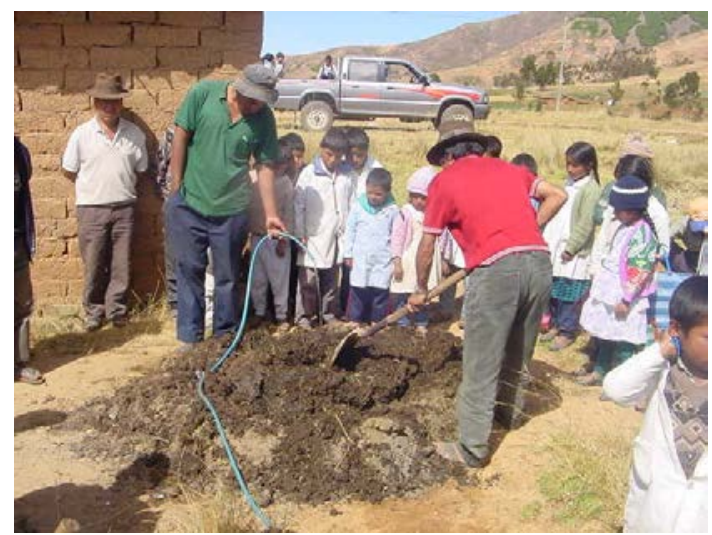

b.

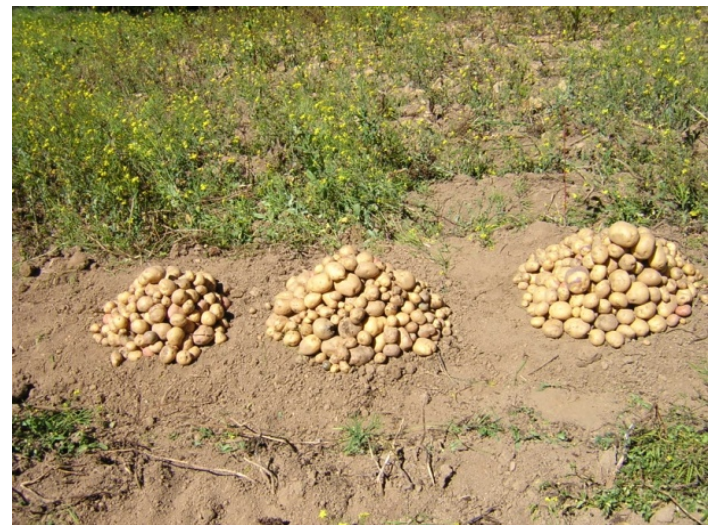

Figure 1. (a) Farmers preparing compost with post-harvested organic residues for incorporation in a potato crop. (b) Tuber yield with locally prepared compost (right), chemical fertilizer (center) and commercial compost (left), in Chullchunqani, Cochabamba, Bolivia 
a.

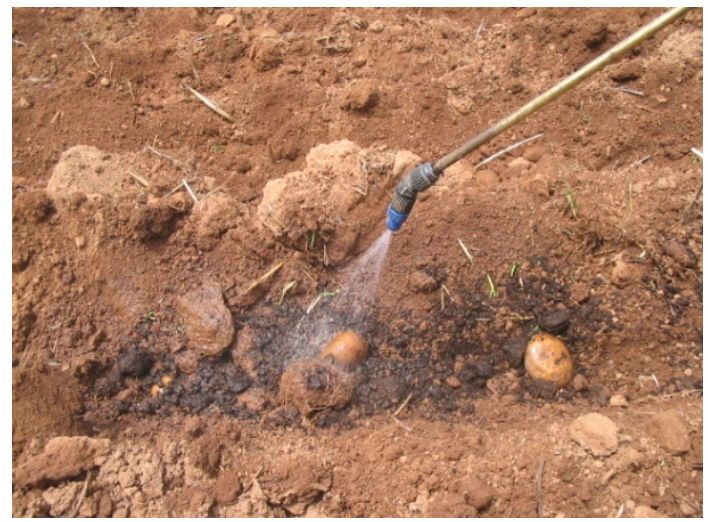

b.

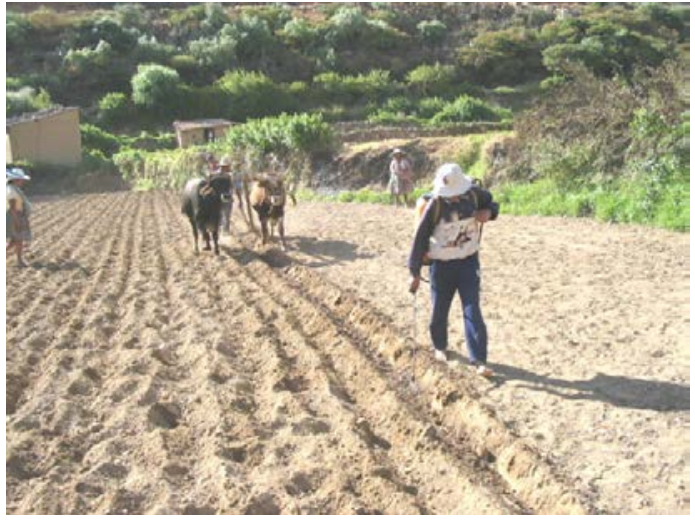

Figure 2. Biofertilizer application at planting time by spraying potato tubers placed on bottom of open furrows

After four years, nearly full achievement of the project's proposed objectives was reached, a "success story" by small Andean farmers of rural and peri-urban areas in Cochabamba, Bolivia. Farmers were able to prepare their own compost using post-harvest organic residues and animal manures for field incorporation at planting of $7 \mathrm{t} / \mathrm{ha}$. Several native isolates of 
PGPR and AMF were identified from B. amyloliquefaciens and $G$. intraradices, respectively. Later on, a commercial $B$. subtilis product (BZF 24WP), was locally multiplied and formulated, and along with a Bolivian commercial mycorrhiza of $G$. fasciculatum (DESAmic), a biofertilizer named "FertiTrap" was formulated and evaluated in several in farmer field trials. Results with potato showed both, plant growth promoting, and suppressive/inhibitory soil born disease effect. When native $B$. amyloliquefaciens became available it was locally multiplied and, leading to the formulation of a bio fertilizer called "BioFert". Hence, the" FertiTrap " biofertilizer was formulated using $B$. subtilis, and the "BioFert" with B. amyloliquefaciens; and both used mycorrhiza (G. fasciculatum) as micro-inoculant and vermicompost as inert material.

Results obtained with the new potato biofertilizers (Figure 2) required less number of traditional pesticide applications and no chemical fertilizers. As demand for bio fertilizers by organic and conventional producers was high a small pilot plant was set up for preparing small volumes of product with similar quality to of commercial bio fertilizers.

As proposed here, increased productivity of native or improved potato varieties and development of eco-efficient technologies, and combining biodiversity friendly agricultural practices, will contribute to decrease current pressure on land use, erosion, and ecological imbalance, alleviating at the same time poverty by increasing incomes of rural farmers' households.

\section{Acknowledgments}

This study is part of the Project INCO-DEV, ICA4-CT-200210016 (2002-2007): "Sustainable potato production in Andean urban and peri-urban areas by combining bio-composting and microbial inoculants"(Producción sostenible de papa en áreas urbanas y peri-urbanas de los Andes mediante la combinación de biocompostamiento e inoculantes microbiales), funded by the European Community, and was fundamental in pioneering the formulation of bio-products based on microorganism in Bolivia. 


\section{References}

Bianciotto, V.; P. Bonfante. 2002. Arbuscular mycorrhizal fungi: a specialized niche for rhizospheric and endocellular bacteria. Antonie Leeuwenhoek, 81: 365-371.

Davies Jr., F.T.; C.M.Calderon; Z. Huaman; R. Gomez. 2005. Influence of a flavonoid on mycorrhizal acitivity in the highlands of Peru. Sci. Hort. 106, 318-329.

de Freitas, J.R.; M.R.Banerjee; J.J. Germida. 1997. Phosphatesolubilizing rhizobacteria enhance the growth and yield but not phosphorus uptake of canola (Brassica napus L.). Biol. Fertil. Soils, 24: 358-364.

Duffy, E M; A.C. Cassells. 1999. The effect of inoculation of potato (Solanum tuberosum L.) microplants with arbuscular mycorrhizal fungi on tuber yield and tuber size distribution. Appl. Soil Ecol. 15: 137-144.

FAOSTAT, 2008. http://faostat.fao.org

Fliessbach A.; H-R. Oberholzer; G. Lucie; P.Maeder P. 2007. Soil organic matter and biological soil quality indicators after 21 years of organic and conventional farming. Agriculture, Ecosystems and Environment, 118, 273-284.

Franco, J.; N. Ortuño; J. Herbas. 2004. Potencial rehabilitación de tierras degradadas por el desarrollo y uso de un biofertilizante en beneficio de los agricultores pobres de Bolivia. Agroecología LEISA Vol. 19, N 4: 32

Glick, B.R.. B.Todorovic; J. Czarny; Z.Cheng; J. Duan; B. McConkey. 2007. Promotion of plant growth by bact0erial ACC deaminase. Crit. Rev. Plant Sci. 26: 227-242.

International Potato Center (CIP). 2007. Facts and figures: Improvement and conservation.

http://www.cipotato.org/pressroom/facts figures/improvement conserv ation.asp

Joo, G.-J.; Y. M. Kim; I-J Lee; K-S. Song; I.-K. Rhee. 2004. Growth promotion of red pepper plug seedlings and the production of 
gibberellins by Bacillus cereus, Bacillus macroides, and Bacillus pumilus. Biotechnol. Lett. 26: 487-491.

Karlen, D.L.; M. Mausbach; J.Doran; R.Cline; R. Harris; G. Schuman. 1997. Soil quality: a concept, definition and framework for evaluation. Soil Sci. Soc. Am. J. 61,4-10.

Lal, R. 2000. Soil management in developing countries. Soil Science 165(1), 57-72.

Liu, A.; C. Hamel; R.I. Hamilton; B.L.Ma; D.L. Smith. 2000. Acquisition of $\mathrm{Cu}, \mathrm{Zn}, \mathrm{Mn}$, and Fe by mycorrhizal maize (Zea Mays L.) grown in soil at different $\mathrm{P}$ and micronutrient levels. Mycorrhiza, 9: 331-336.

Mallory E. B.; G.A. Porter. 2007. Potato yield stability under contrasting soil

Management strategies. Agron. J., 99, 501-510.

MINAG - Ministerio de Agricultura de Perú. 2007. Importancia de las papas nativas.

http://www.portalagrario.gob.pe/papa datos.shtml

Rodriguez, H.; R.Fraga. 1999. Phosphate solubilizing bacteria and their role in plant growth promotion. Biotechnol. Adv. 17: 319-339.

Rovira A.D. 1979. Biology of the soil root interface. In: Harley J.L., Russell R.S. (eds.). The soil root interface. Academic Press London, pp. $145-160$.

Schmiedeknecht G.; H. Bochow; H. Junge. 1998. Use of Bacillus subtilis as biocontrol agent II. Biological control of potato diseases. Journal of Plant Disease Protection 105: 376-386.

Sheng, X.F.; L.Y.He. 2006. Solubilization of potassium-bearing minerals by a wild-type strain of Bacillus edaphicus and its mutants and increased potassium uptake by wheat. Can. J. Microbiol. 52: 6672.

Stewart, L. I.; C.Hamel; R. Hogue; P.Moutoglis. 2005. Response of strawberry to inoculation with arbuscular mycorrhizal fungi under very high soil phosphorus conditions. Mycorrhiza, 15: 612-619. 